\title{
Rubidium measured by XRF as a predictor of soil particle size in limestone and siliceous parent materials
}

\author{
Maame E. T. Croffie ${ }^{1,2}$ - Paul N. Williams ${ }^{1} \cdot$ Owen Fenton $^{2} \cdot$ Anna Fenelon $^{2} \cdot$ Karen Daly $^{2}$
}

Received: 20 July 2021 / Accepted: 6 November 2021 / Published online: 14 December 2021

(C) The Author(s) 2021

\begin{abstract}
Purpose Information about particle size distribution (PSD) and soil texture is essential for understanding soil drainage, porosity, nutrient availability, and trafficability. The sieve-pipette/gravimetric method traditionally used for particle size analysis is labour-intensive and resource-intensive. X-ray fluorescence (XRF) spectrometry may provide a rapid alternative. The study's aim was to examine the use of XRF for rapid determination of PSD in Irish soils.

Methods Soils $(n=355)$ from existing archives in Ireland were analysed with a benchtop energy-dispersive XRF (EDXRF). Correlation and regression analyses were determined to compare $\mathrm{Rb}, \mathrm{Fe}, \mathrm{Al}$, and $\mathrm{Si}$ concentrations to \% clay, \% silt, and $\%$ sand. Also, linear regression models were developed to compare $\%$ clay, $\%$ sand, and $\%$ silt measured by the gravimetric method to values predicted by EDXRF.

Results The relationship between element concentration and PSD was dependent on parent material. Rb, Al, and Fe showed a significant $(p<0.05)$ correlation $(r>0.50)$ with \% clay and \% sand in soils derived from limestone and siliceous stone parent materials. $\mathrm{Rb}$ was the best predictor for $\%$ clay $\left(R^{2}=0.49, \mathrm{RMSE}=10.20\right)$ in soils derived from limestone and siliceous stone-derived soils.

Conclusion Geochemistry and clay mineralogy of the soils' parent material strongly influenced the EDXRF's ability to predict particle size. The EDXRF could predict \% clay in soils from parent materials which weather easily, but the opposite was true for soils with parent material recalcitrant to weathering. In conclusion, this study has shown that the EDXRF can screen $\%$ clay in soils derived from limestone and siliceous stone parent materials.
\end{abstract}

Keywords Rubidium $\cdot$ EDXRF $\cdot$ Parent material $\cdot \%$ clay $\cdot$ Particle size

\section{Introduction}

Soil texture is an important property that affects a soil's function, water retention, and distribution of nutrients and trace elements (Dexter et al. 2004; Acosta et al. 2011; Rabot et al. 2018; Schweizer et al. 2019; ). Also, knowledge

Responsible editor: Claudio Colombo

Maame E. T. Croffie

mcroffie01@qub.ac.uk

1 Institute for Global Food Security, School of Biological Sciences, Queen's University Belfast, Belfast BT9 5DL, Northern Ireland, UK

2 Environment, Soils and Land Use Department, Teagasc Johnstown Castle Research Centre, Wexford Y35 TC97, Ireland about soil texture or particle size distribution helps measure bulk density and soil organic matter (Dexter et al. 2004; Keller et al. 2010; Prout et al. 2020). However, the sector standard for determination of soil texture involves quantification of $\%$ clay, $\%$ silt, and $\%$ sand with the sieve-pipette method. This process was developed nearly 40 years ago by Gee and Bauder (1986) and requires several lengthy pre-treatment stages (Jensen et al. 2017), whereby soil organic matter is removed in the first step by treating dried and sieved soils with hydrogen peroxide $\left(\mathrm{H}_{2} \mathrm{O}_{2}\right)$ overnight. After which, more $\mathrm{H}_{2} \mathrm{O}_{2}$ is added, and the solution is heated, followed by the addition of $\mathrm{NH}_{4} \mathrm{OH}$ to decompose any remaining $\mathrm{H}_{2} \mathrm{O}_{2}$. Deionised water and sodium hexametaphosphate are then added, and the samples are left on an end-over-end shaker for $16 \mathrm{~h}$. The solution is decanted in sieves with different mesh sizes to collect coarse and fine sand particles, and part of the solution is poured into 
crucibles and oven dried overnight. The remaining liquid is left in a temperature-controlled water bath for a few hours to settle. Thereafter, the solution is shaken, and aliquots are taken for silt and clay content and oven dried overnight, the process is then repeated for sampling of clay content. Consequently, the process is time-consuming and labourintensive, with it taking about 2-3 days to obtain results for a sample, and only about 20 samples can be analysed in a typical laboratory per week.

In recent years, rapid techniques for particle size analysis such as the laser diffraction method have been developed; however, this method overestimates and sometimes underestimates \% clay in some soil types due to the particle morphology (Beuselinck et al. 1998; Taubner et al. 2009). Fenton et al. (2015) indicate that altering the clay/silt particle size boundary during analysis with the laser diffraction method can compensate for the overestimation and underestimation of $\%$ clay in some soil types. However, these systems are still expensive to acquire and do not provide additional data other than particle size.

According to Lucadamo and Leone (2015), spectrometry techniques coupled with mathematical models such as chemometrics can be effective methods for predicting soil texture. X-ray fluorescence spectrometry (XRF) is a suitable rapid and cost-effective method for measuring trace elements and macronutrients in various environmental samples, including soil with the additional advantage of being portable ( Kalnicky et al. 2001; Melquiades and Appoloni 2004; Wu et al. 2012; Rouillon and Taylor 2016; Melquiades et al. 2019; Croffie et al. 2020). XRF measured elements such as rubidium $(\mathrm{Rb})$ have been found to strongly correlate with \% clay and \% sand in soils from different countries (Zhu et al. 2011; Tóth et al. 2019).

$\mathrm{Rb}$ is strongly adsorbed to clay minerals in weathered soils; however, it does not form its own minerals, but it is present in the interlayer sites of mica as a replacement for K (Wampler et al. 2012; Zaunbrecher et al. 2015). $\mathrm{Rb}$ is also present in illite and montmorillonite as it has similar ionic radii with $\mathrm{K}$ (Négrel et al. 2018; Swetha and Chakraborty 2021). Although Rb and $\mathrm{K}$ are strongly correlated in soils, the use of $\mathrm{K}$ as an indicator to predict \% clay may not be feasible since $\mathrm{K}$ concentration in soils is influenced by plant uptake and the application rate of fertilisers (Fay et al. 2007; Tóth et al. 2019). Comparatively, $\mathrm{Rb}$ is seldom added to agricultural soils, and it is not mobile; hence, its concentration can better reflect the physico-chemical properties of soil.

In addition, other elements such as $\mathrm{Fe}, \mathrm{Si}$, and $\mathrm{Al}$ have been found to strongly correlate with \% sand and \% clay; thus, correlation between these elements and particle size distribution results from the mineralogy of the soils due to their parent material and weathering-leaching degree (O'Rourke et al. 2016; Silva et al. 2020; Swetha and Chakraborty 2021). Soils from certain areas are rich in Fe, $\mathrm{Si}$, and $\mathrm{Al}$ oxides, hydroxides, and silicate minerals such as phyllosilicates and tectosilicates; also $\mathrm{Al}$ and $\mathrm{Fe}$ can be found in the clay fractions, with $\mathrm{Si}$ in the sand fraction; thus, the chemical composition of the soils is related to soil texture (Zhu et al. 2011; O' Rourke et al. 2016; Silva et al. 2020). It is important to note that although these studies used portable XRF, sample analyses were done under laboratory conditions and not in the field. For example, the soils were dried, sieved ( $2 \mathrm{~mm}$ mesh), and measured as loose powders. Improvements to the accuracy of the XRF analysis can be achieved with sample preparation techniques such as pressed pellet or fused beads (Shibata et al. 2009; Markowicz 2011; Takahashi 2015; Schneider et al. 2016; Takahashi 2015; Ichikawa and Nakamura 2016) but also by using Cartesian geometry EDXRF benchtop systems operated under vacuum atmosphere (Croffie et al. 2020).

Despite XRF measurement having been shown as a suitable technique for soil texture prediction in Indian, Brazilian, and Australian soils (O'Rourke et al. 2016; Silva et al. 2020; Swetha and Chakraborty 2021), there is limited research on XRF use to predict particle size distribution (PSD) in Irish soils. Geology and climate have a notable influence on soil formation in Ireland; thus, the country has a unique landscape, whereby the soil parent material's chemical and physical properties differ over short distances (Meere et al. 2013; Creamer et al. 2007). The parent materials in Ireland are mostly comprised of solid bedrock geology or bedrock-derived glacial geology, and the soils are formed from the retreat of glacial deposits (Holland and Sanders 2009; Ballantyne et al. 2011a, b; Meere et al. 2013; Creamer and O'Sullivan 2018). Also, Ireland has a mild maritime climate due to its location on the North East side of the Atlantic Ocean where it forms the western fringe of Europe (Creamer and O'Sullivan 2018). Thus, precipitation is higher in the west and declines as it tracks to the east (Domonkos et al. 2020). The country's weather is characterised by cool winters and mild summers and has a varied rainfall pattern with the highest annual precipitation $(>3000 \mathrm{~mm}$ ) recorded in the mountainous regions of the west and south west, and annual precipitation is $<750 \mathrm{~mm}$ in parts of the east (Creamer and O'Sullivan 2018; Domonkos et al. 2020).

The main objective of this study was to explore the use of benchtop XRF as a rapid screening method to predict PSD in Irish soils. Another objective was to determine the best elemental parameter to predict PSD using simple linear regression models. We hypothesised that XRF measured elements coupled with regression models can predict $\%$ clay, $\%$ sand, and $\%$ silt in Irish soils. 


\section{Materials and method}

\subsection{Sample selection}

This study used archived soils and data from two independent projects in the Republic of Ireland (ROI), namely the Irish Soil Information System (Irish SIS) and the Heavy Soil Programme (HSP). The Irish SIS consolidated existing information on the distribution of soil types in Ireland and created a 1:250,000 scale soil map with an archive of modal profiles and an accompanying database (Creamer et al. 2007; Creamer and O'Sullivan 2018). In addition, a new soil classification system for the country was generated by harmonising data for the SIS survey and previous soil surveys, thereby creating a soil classification consisting of three levels: great groups, soil subgroups, and series (Simo et al. 2019). The soils used for this study have been classified according to World Reference Base for Soil Resources (IUSS WG WRB 2015) and can be found in Supplementary Table ST1. Also, the details of the soil map of Ireland can be found here: https://gis.teagasc.ie/soils/.

The HSP is an ongoing project at Teagasc since 2011 that aims to improve grass growth on heavy textured soils by implementing appropriate land management systems (www.teagasc.ie/crops/grassland/heavy-soils/). An available archive of soil samples with an accompanying database representing 10 farms enrolled on this programme was used for independent validation of the linear regression models; however, the soil types featured did not cover as wide a range as the SIS data (calibration set). Samples with existing information on the parent material were randomly selected from the SIS samples archive. A total of 308 mineral soils covering a range of soil types and land use were selected and used to develop particle size predictions from XRF data. In addition, archived samples and data from the HSP $(n=47)$ were selected from the HSP project as a validation set. Figure 1 shows a map of Ireland highlighting the origin of the calibration and validation samples, and Supplementary Table ST2 shows the distribution of the samples on the selected counties based on parent material.

For the final analysis, the SIS data were separated based on the parent material of the soils. Furthermore, 27 soils with no parent material information along with soils from Chert, Schist, and Old Redstone parent materials were eliminated from the SIS dataset due to their small sample size $(n<5)$. To explore the relationship between element
Fig. 1 Map of Ireland showing the counties where the calibration and validation sets originate

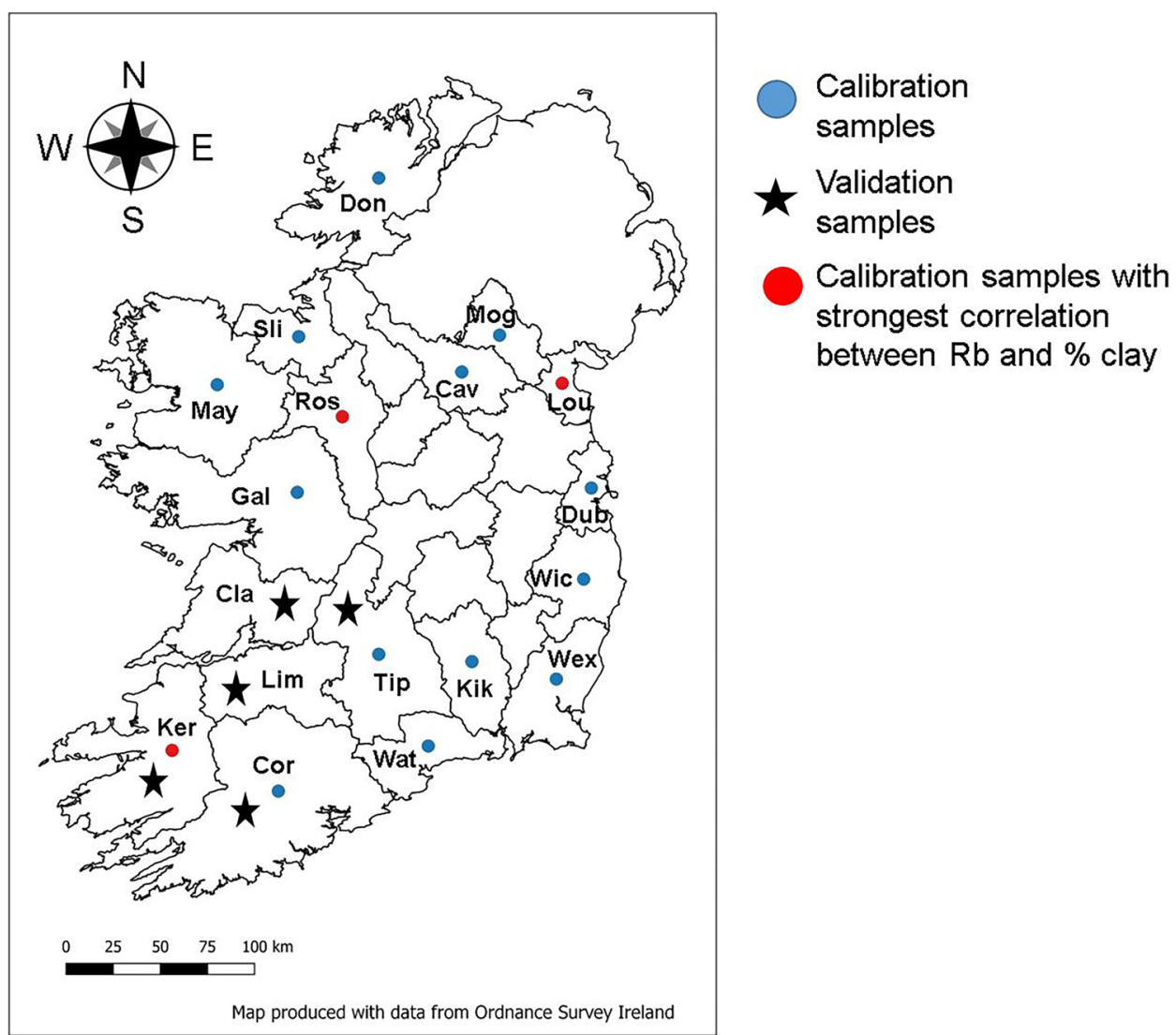


concentration and PSD, only samples from limestone, shale, siliceous stones, sandstone, slate, and quartzite were considered which are the most representative of Ireland's parent material. Also, from percentile analysis performed on the SIS data, samples with $\mathrm{Rb}>150 \mathrm{mg} \mathrm{kg}^{-1}$ were not considered for calibration since $90 \%$ of the samples were below $150 \mathrm{mg} \mathrm{kg}^{-1}$. Moreover, 4 samples with clay $>50 \%$ were not considered as these are rarely found on agricultural soils in Ireland. Prior to this, the data was divided into different $\mathrm{Rb}$ concentration bands based on an Rb distribution map by Fay et al. (2007). A decision tree showing the selection process is shown in Supplementary Fig. SF1.

\subsection{Sample preparation}

Soil samples which had been dried at $40{ }^{\circ} \mathrm{C}$ and sieved at $2 \mathrm{~mm}$ were retrieved from long-term storage and mixed thoroughly using the coning and quartering method described by Gerlach and Nocerino (2003). To obtain a representative sample, a cone was formed with the soil sample initially; the cone is then flattened and divided into quarters. Opposite quarters are discarded and the remaining quarters are mixed and another cone is formed. A sub-sample is then taken from the newly formed cone. Representative samples were then made into a pressed pellet with a binder using $8 \mathrm{~g}$ of soil plus $2 \mathrm{~g}$ of a wax binder, with 20 tons of pressure then added to create the pellet (Croffie et al. 2020).

\subsection{EDXRF analysis}

All soil samples were analysed with a benchtop Rigaku NEX-CG EDXRF. The instrument is equipped with a nineplace sample holder with a spin function, a palladium X-ray tube, and a silicon drift detector. It uses secondary targets at Cartesian geometry to improve the detection of trace elements. The targets used for this study were Al, Mo, Rx9, Si, and $\mathrm{Cu}$. Samples were scanned under a vacuum atmosphere.
A library calibration is made weekly using pure elements, namely $\mathrm{Cu}, \mathrm{Sn}$, and $\mathrm{SiO}_{2}$ to check for instrument drift. All samples were run with the in-built fundamental parameters calibration. A multichannel analyser (MCA) was used as a drift monitor before analysis daily to check the instrument's stability. Furthermore, certified reference materials (CRMs), ISE 921, BAM-U110, and NCS DC85108, were run after every 40 samples to check the instrument's accuracy. The recovery (measured value/certified value*100) (Rouillon and Taylor 2016; Croffie et al. 2020) of the elements was calculated and shown in Table 1.

\subsection{Data analysis}

Descriptive statistics were performed in MS-Excel 2016. Pearson correlation $(r)$, coefficient of determination $\left(R^{2}\right)$, root mean square error (RMSE), and the significance of the data $(p<0.05)$ were analysed with GraphPad Prism 9.0 and MS-Excel 2016. All graphs were plotted with GraphPad Prism 9.0. Regression models were made with the same software to compare element data derived from the EDXRF to the sieve-pipette method's (Gee and Bauder 1986) particle size results. The equation of the line $y=m x+c$ of the regression models was used to predict particle size where $x=\%$ PSD, $y=$ element concentration, $c=y$-intercept, and $m=$ slope. Thus, for the predicted \% PSD using the validation set, $x$ was considered the unknown variable; therefore, to predict the \% PSD with XRF, this equation was used: $x=(y-c) / m$.

\section{Results and discussion}

\subsection{Selection of elements for calibration models}

In this study, 7 elements were initially selected to examine their association with soil PSD fractions, namely $\mathrm{Rb}, \mathrm{Al}$,

Table 1 Data for certified reference materials

\section{CRMS}

\begin{tabular}{|c|c|c|c|c|c|c|}
\hline \multirow[b]{2}{*}{ Elements } & \multicolumn{2}{|c|}{ ISE 921} & \multicolumn{2}{|c|}{ NCS DC85108 } & \multicolumn{2}{|c|}{ BAM-U110 } \\
\hline & ${ }^{\mathrm{a}} \mathrm{Cv}$ & Recovery (\%) & ${ }^{\mathrm{a}} \mathrm{Cv}$ & Recovery (\%) & ${ }^{\mathrm{a}} \mathrm{Cv}$ & Recovery (\%) \\
\hline$\overline{\mathrm{Al}\left(\mathrm{g} \mathrm{kg}^{-1}\right)}$ & 56.8 & 103 & 67.6 & 102 & $* 50.4$ & 109 \\
\hline $\mathrm{Ca}\left(\mathrm{g} \mathrm{kg}^{-1}\right)$ & 43.0 & 107 & 32.6 & 121 & $* 40.6$ & 122 \\
\hline $\mathrm{Fe}\left(\mathrm{g} \mathrm{kg}^{-1}\right)$ & 31.9 & 98 & 31.4 & 99 & $* 28.2$ & 100 \\
\hline $\operatorname{Mg}\left(\mathrm{g} \mathrm{kg}^{-1}\right)$ & 11.10 & 107 & 12.1 & 124 & $* 8.4$ & 139 \\
\hline $\mathrm{Si}\left(\mathrm{g} \mathrm{kg}^{-1}\right)$ & 271 & 77 & $\mathrm{~W}$ & $\mathrm{~W}$ & $\mathrm{~W}$ & 87 \\
\hline $\operatorname{Mn}\left(\mathrm{mg} \mathrm{kg}^{-1}\right)$ & 1190 & 103 & 596 & 109 & 621 & 112 \\
\hline $\mathrm{Rb}\left(\mathrm{mg} \mathrm{kg}^{-1}\right)$ & 103 & 106 & - & - & $* 87.5$ & 121 \\
\hline
\end{tabular}

${ }^{\text {a }} C v$ certified value

*Reference value only not certified 
Table 2 Summary of descriptive statistics for soil samples from the Irish Soil Information System (SIS) $(n=308)$ (calibration samples)

\begin{tabular}{lllll}
\hline Soil parameters & Mean & Median & Min & Max \\
\hline $\mathrm{Si}\left(\mathrm{g} \mathrm{kg}^{-1}\right)$ & $182 \pm 45$ & 183.0 & 16.9 & 336 \\
$\mathrm{Al}\left(\mathrm{g} \mathrm{kg}^{-1}\right)$ & $51 \pm 19.2$ & 50.95 & 2.8 & 117 \\
$\mathrm{Fe}\left(\mathrm{g} \mathrm{kg}^{-1}\right)$ & $29 \pm 13.3$ & 29.0 & 2.0 & 68.4 \\
$\mathrm{Ca}\left(\mathrm{g} \mathrm{kg}^{-1}\right)$ & $15 \pm 45.1$ & 2.88 & 0.06 & 283 \\
$\mathrm{Mg}\left(\mathrm{g} \mathrm{kg}^{-1}\right)$ & $5.6 \pm 4.2$ & 4.81 & 1.03 & 42.4 \\
$\mathrm{Mn}\left(\mathrm{mg} \mathrm{kg}^{-1}\right)$ & $619 \pm 718$ & 503 & 34.2 & 6240 \\
$\mathrm{Rb}\left(\mathrm{mg} \mathrm{kg}^{-1}\right)$ & $95 \pm 42.7$ & 92.3 & 5.21 & 248 \\
$\mathrm{Sand}(\%)$ & $47 \pm 22.8$ & 45.5 & 2 & 95 \\
$\mathrm{Silt}(\%)$ & $32 \pm 13.3$ & 33 & 1 & 77 \\
Clay $(\%)$ & $22 \pm 12.8$ & 21 & 2 & 64 \\
\hline
\end{tabular}

$\mathrm{Fe}, \mathrm{Si}, \mathrm{Mn}, \mathrm{Ca}$, and $\mathrm{Mg}$. Three CRMs (Table 1) consisting of different concentrations of the elements were routinely analysed to check the measurement accuracy of the EDXRF. From Table 1, the lowest recovery observed was $77 \%$ for $\mathrm{Si}$ at a concentration of $271 \mathrm{~g} \mathrm{~kg}^{-1}$, and the highest recovery was $139 \%$ for $\mathrm{Mg}$ at $8.4 \mathrm{~g} \mathrm{~kg}^{-1}$. However, the recoveries for most elements (Table 1) were within the benchmark of $100 \% \pm 20 \%$ for measurement accuracy (Rouillon and Taylor 2016; Sacristán et al. 2016). A summary of the range of concentrations for the selected elements and PSD for the calibration and validation sets is shown in Tables 2 and 3, respectively.

The study focussed on significant associations between $\mathrm{Rb}$ and particle size. However, $\mathrm{Al}, \mathrm{Si}, \mathrm{Fe}, \mathrm{Mg}, \mathrm{Ca}$, and $\mathrm{Mn}$ were also considered, and significant correlations between the selected elements and particle size fractions were examined to determine which elements were associated with PSD. A summary of the correlation results between the elements and PSD is shown in Table 4. There was a significant positive correlation between $\mathrm{Rb}$ and $\%$ clay $\left(r=0.27, R^{2}=0.07\right)$ and $\mathrm{Fe}$ and $\%$ clay $\left(r=0.39, R^{2}=0.15\right)$ (Table 4$)$ and a negative correlation between $\mathrm{Rb}$ and $\%$ sand $\left(r=-0.24, R^{2}=0.06\right)$ and $\mathrm{Fe}$ and $\%$ sand $\left(r=-0.49, R^{2}=0.24\right)$ (Table 4). There was no significant correlation between $\%$ clay and $\mathrm{Mn}$ and $\%$ sand and \% silt with both $\mathrm{Mg}$ and $\mathrm{Mn}$. Although Ca had a significantly positive correlation $(r=0.17)$ with $\%$ sand and a negative correlation with both $\%$ clay $(r=-0.19)$ and $\%$ silt $(r=-0.11)$ (Table 4$)$, the $R^{2}$ was $<0.10$.
From the initial correlation results stated above, $\mathrm{Rb}$ and Fe had a stronger relationship with \% clay in Irish soils compared to the other elements. Previous studies by Tóth et al. (2019) and Zhu et al. (2011) found a stronger relationship between $\mathrm{Rb}$ and \% clay $(r>0.80)$ in soils from Hungary and the USA, respectively, using portable XRF. However, unlike the previous studies, the initial correlation coefficient for this study was lower $(r=0.27)$ (Table 4$)$. Compared to previous studies, the weaker relationship observed in this study was not influenced by the instrument's accuracy as the recovery for $\mathrm{Rb}$ was within the benchmark of $100 \% \pm 20 \%$ (Table 1 ). Moreover, the benchtop EDXRF used for the current study is equipped with secondary targets at Cartesian geometry, improving the sensitivity of trace elements such as Rb by reducing background intensity; thus, it is more sensitive/ accurate and precise than the portable XRF (Bisgård et al. 1981; Zarkadas et al. 2001; Manousakas et al. 2018).

Also, the $\mathrm{Rb}$ peaks on the Mo targets were checked visually for any influence of background intensity using samples with low $\left(5.52 \mathrm{mg} \mathrm{kg}^{-1}\right)$ to high concentration $\left(213 \mathrm{mg} \mathrm{kg}^{-1}\right.$ ) (Supplementary Fig. SF2). No influence of the background intensity was found with concentrations above $24.4 \mathrm{mg} \mathrm{kg}^{-1}$, also the average concentration of $\mathrm{Rb}>90 \mathrm{mg} \mathrm{kg}^{-1}$ (Tables 2 and 3) in Irish soils is above this threshold. Furthermore, in certain soil types whereby the particle size is larger than that of clay, such as sand, the EDXRF suffers from particle size effects resulting from variable particle size when using the pressed pellet sample preparation method (Croffie et al. 2020). However, from previous research (Croffie et al. 2020), the addition of the wax binder during sample preparation may reduce this effect by filling up the spaces between the coarse grains. Also, particle size is more pronounced in analysis of light elements such as $\mathrm{P}, \mathrm{Mg}$, and $\mathrm{S}$ with shallow analytical depth. However, Ichikawa and Nakamura (2016) estimated the analytical depth of $\mathrm{Rb}$ using igneous rock to be $800 \mu \mathrm{m}$ which is deep enough for the EDXRF to measure accurately the concentration of Rb. In addition, Potts et al. (1997) indicates that the critical analytical depth that represents $99 \%$ of the XRF signal ranges from 632 to $1086 \mu \mathrm{m}$ in silicate rocks. This shows that the EDXRF can accurately detect $\mathrm{Rb}$ at even low concentrations as shown in Supplementary Fig. SF2 unlike certain elements such as $\mathrm{P}$ and $\mathrm{S}$. Based on this, the Irish
Table 3 Summary data for the independent validation set from the heavy soils programme (HSP) consisting of soils originating from limestone, shale, and siliceous stone parent materials $(n=47)$

\begin{tabular}{llllllll}
\hline & Sand (\%) & Silt (\%) & Clay (\%) & $\mathrm{Si}\left(\mathrm{g} \mathrm{kg}^{-1}\right)$ & $\mathrm{Al}\left(\mathrm{g} \mathrm{kg}^{-1}\right)$ & $\mathrm{Fe}\left(\mathrm{g} \mathrm{kg}^{-1}\right)$ & $\mathrm{Rb}_{\left(\mathrm{mg} \mathrm{kg}^{-1}\right)}$ \\
\hline Mean & 26.4 & 45.6 & 28 & 187 & 56.3 & 27.4 & 93.9 \\
Stdev & 16.6 & 12.2 & 8.7 & 46.5 & 17.2 & 12.4 & 27.7 \\
Min & 7 & 10 & 6 & 30.2 & 9.9 & 8.7 & 21.1 \\
Median & 21 & 46 & 29 & 190 & 57.8 & 26.5 & 95.6 \\
Max & 84 & 67 & 47 & 251 & 84.3 & 57.4 & 144 \\
\hline
\end{tabular}


Table 4 Correlation of elements with particle size distribution

\begin{tabular}{lrrrrrrrrrr}
\hline & \multicolumn{1}{c}{ Sand } & \multicolumn{1}{c}{ Silt } & Clay & $\mathrm{Mg}$ & $\mathrm{Al}$ & $\mathrm{Si}$ & $\mathrm{Ca}$ & $\mathrm{Mn}$ & $\mathrm{Fe}$ & $\mathrm{Rb}$ \\
\hline Sand & 1.00 & & & & & & & & & \\
Silt & -0.88 & 1.00 & & & & & & & & \\
Clay & -0.87 & 0.55 & 1.00 & & & & & & & \\
$\mathrm{Mg}$ & -0.02 & 0.08 & -0.06 & 1.00 & & & & & & \\
$\mathrm{Al}$ & -0.31 & 0.38 & 0.16 & 0.45 & 1.00 & & & & & \\
$\mathrm{Si}$ & -0.07 & 0.20 & -0.08 & 0.08 & 0.34 & 1.00 & & & & \\
$\mathrm{Ca}$ & 0.17 & -0.11 & -0.19 & 0.04 & -0.49 & -0.44 & 1.00 & & & \\
$\mathrm{Mn}$ & -0.09 & 0.13 & 0.02 & 0.06 & 0.06 & -0.08 & -0.08 & 1.00 & & \\
$\mathrm{Fe}$ & -0.49 & 0.46 & 0.39 & 0.37 & 0.64 & 0.04 & -0.37 & 0.40 & 1.00 & \\
$\mathrm{Rb}$ & -0.24 & 0.15 & 0.27 & 0.06 & 0.59 & -0.06 & -0.42 & 0.10 & 0.42 & 1.00 \\
\hline
\end{tabular}

dataset had a unique relationship between $\mathrm{Rb}$ and clay compared to the other soils (Zhu et al. 2011; Tóth et al. 2019).

\subsection{Analysis of relationship between clay content and $\mathbf{R b}$ based on location}

When the data was divided into four different $\mathrm{Rb}$ concentration groups based on an Rb distribution map of Ireland by Fay et al. (2007), no strong association between Rb and \% clay emerged (Supplementary Fig. SF3). Rb is found in clay fractions of the soil after weathering and $\mathrm{Rb}$ increases with increasing clay fractions; thus, in American soils (specifically soils from Louisiana and Capulin, New Mexico), there was a strong correlation $(r>0.80)$ between $\mathrm{Rb}$ and \% clay (Zhu et al. 2011). However, from Supplementary Fig. SF3, the opposite is true for the Irish soils, whereby correlation was weak $(r<0.30)$ between $\mathrm{Rb}$ in concentrations from 40 to $60 \mathrm{mg} \mathrm{kg}^{-1}, 60$ to $150 \mathrm{mg} \mathrm{kg}^{-1}$, and 150 to $250 \mathrm{mg} \mathrm{kg}^{-1}$. The difference in the Irish soils compared to the American soils may result from different patterns of soil formation as the geology, mineralogy, and climate vary (Zhu et al. 2011; Creamer and O' Sullivan 2018).
The relationship between $\mathrm{Rb}$ and \% clay was examined again based on sample county origin and a trend emerged. Within the SIS dataset, it was observed that a strong relationship exists between $\mathrm{Rb}$ and \% clay for counties Kerry, Louth, and Roscommon with an $R^{2}$ of $0.77,0.66$, and 0.94, respectively, as shown in Fig. 2. Also, the correlation $(r>0.80)$ between $\mathrm{Rb}$ and \% clay in samples from these counties was statistically significant $(p<0.001)$. In addition, from Fig. 2, the regression for Louth and Kerry followed the same trend; however, the regression line for the Kerry samples was steeper than that of Louth. This is similar to the findings of Zhu et al. (2011) who showed that samples from two different locations in the USA followed the same trend of relationship between $\mathrm{Rb}$ and \% clay; however, the authors note that the slope of the Capulin samples was steeper than that of the Louisiana samples. Although the authors' did not give a reason for this and state that the relationship between $\mathrm{Rb}$ and \% clay needs further investigation. However, from this current study, the relationship between $\mathrm{Rb}$ and \% clay could be influenced by the soils' parent material. Moreover, geographically the counties are not very far apart; however,
Fig. 2 Irish counties with soils having a strong correlation between $\mathrm{Rb}$ concentration and $\%$ clay

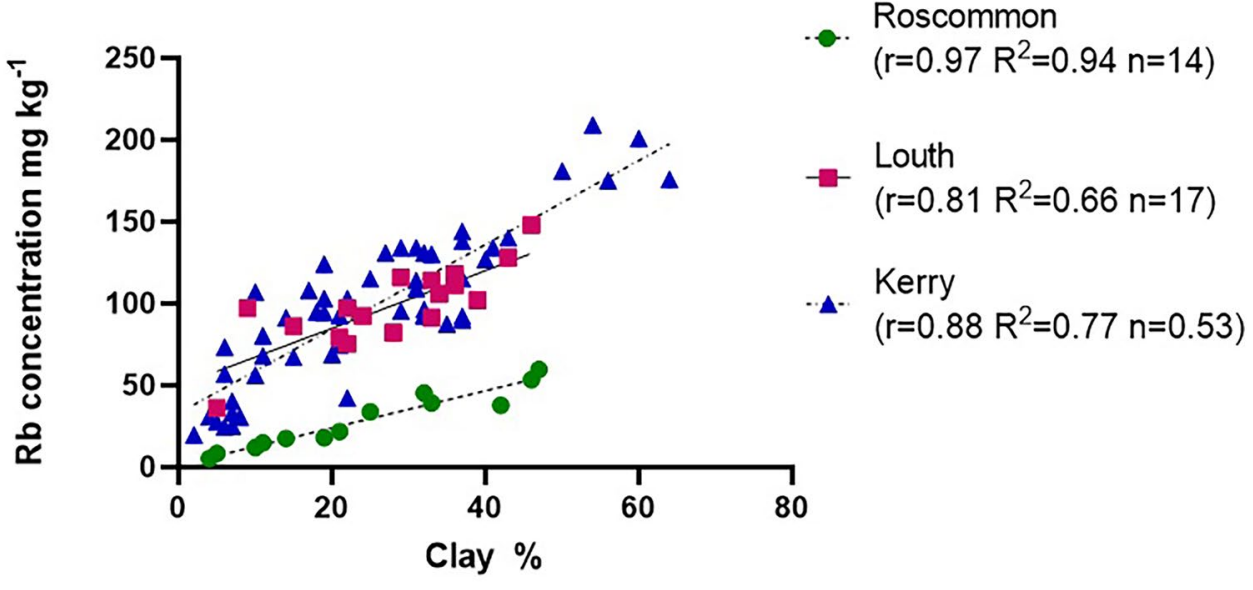


the parent material of the soils in Ireland is highly heterogeneous over short distances (Creamer et al. 2007).

Also, in Fig. 2, the Roscommon samples showed a different trend compared to the Louth and Kerry samples because the concentration of $\mathrm{Rb}$ in samples from Roscommon was lower than the other counties. This again results from the parent material as Roscommon County (Fig. 1) is found in the midlands of Ireland, where the land area is mainly covered with carboniferous limestone bedrock (Holland and Sanders 2009). Limestone parent material usually has low Rb concentrations (Fay et al. 2007; Négrel et al. 2018). Also the Roscommon samples had the strongest association $\left(R^{2}=0.94\right)$ for $\mathrm{Rb}$ with \% clay among the 3 counties.

Silva et al. (2020) state that the stronger correlation between $\mathrm{Rb}$ measured by XRF and \% clay in the samples studied by Zhu et al. (2011) as compared to their Brazilian soils, which showed a poor correlation between $\mathrm{Rb}$ with \% clay, resulted from the weathering patterns of the soils. In this study, the degree of correlation between $\mathrm{Rb}$ and \% clay may result from weathering, geology (i.e. parent material), and mineralogy of the soils as these factors have the strongest influence on the physico-chemical characteristics of soils. Also, from Supplementary Table ST2, most Roscommon soils had limestone parent material, while Kerry and Louth's samples were primarily derived from sandstone and siliceous stone parent materials.

Furthermore, $\mathrm{Rb}$ is closely bound to clay fractions in weathered soils; although it does not form its own minerals, it can replace $\mathrm{K}$ in feldspar and mica and in parent materials such as limestone; these clay fractions have a strong influence on the mechanical behaviour of the bedrock (Wampler et al. 2012; Zaunbrecher et al. 2015; Cherblanc et al. 2016; Négrel et al. 2018). Since Rb is not easily mobile, concentrations of $\mathrm{Rb}$ reflect the physico-chemical properties of a soil. From the results above, it was inferred that the most suitable approach to explore further the relationship between $\mathrm{Rb}$ and $\%$ clay in Irish soils was by grouping the dataset based on the parent materials.

\subsection{Effect of parent material on the correlation of $\mathbf{R b}$ against particle size distribution}

Soils originating from limestone $\left(R^{2}=0.47, r=0.69\right)$, siliceous stones $\left(R^{2}=0.54, r=0.74\right)$, and slate $\left(R^{2}=0.39\right.$, $r=0.63$ ) had a stronger association between $\mathrm{Rb}$ and \% clay (Fig. 3) compared with soils originating from sandstone where $R^{2}=0.21$ and $r=0.45$. The strongest relationship between these parameters was recorded in soils derived from limestone and siliceous stones (Fig. 3). Table 5 shows the summary of correlation and regression results between the selected elements and PSD. Table 5 presents a significant $(p<0.05)$ positive correlation between $\%$ clay and $\mathrm{Rb}$ $(r=0.69), \mathrm{Fe}(r=0.77)$, and $\mathrm{Al}(r=0.63)$ and negative correlation between $\%$ sand and $\mathrm{Rb}(r=-0.66), \mathrm{Fe}(-0.72)$, and $\mathrm{Al}(r=-0.63)$ in soils derived from limestone parent material. However, of the elements selected, $\mathrm{Rb}$ and $\mathrm{Fe}$ had
Fig. 3 Regression plots showing parent material with the good correlation between $\%$ clay and $\mathrm{Rb}$ determined by EDXRF
Limestone

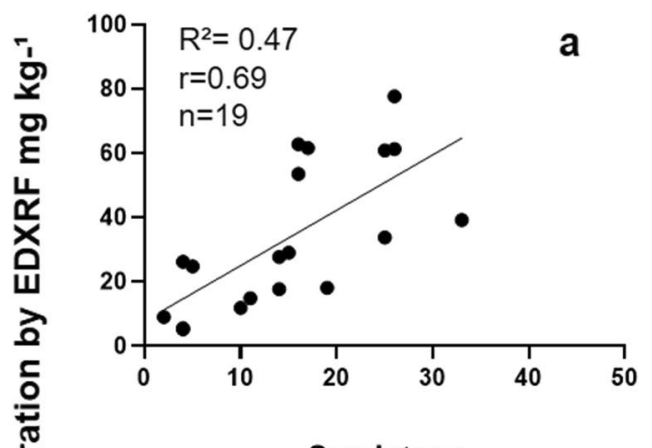

Sandstone

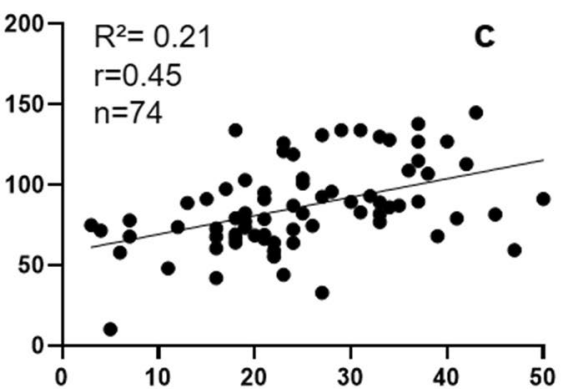

Siliceous stones
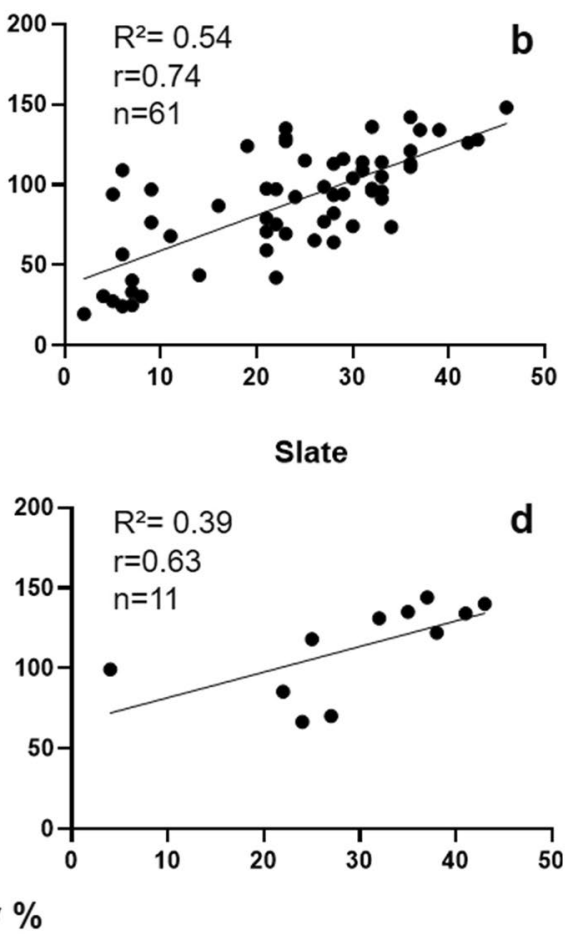
Table 5 Regression and correlation results for elements measured by XRF and particle size distribution

\begin{tabular}{|c|c|c|c|c|c|c|c|c|}
\hline & \multicolumn{2}{|l|}{$\mathrm{Rb}$} & \multicolumn{2}{|l|}{$\mathrm{Fe}$} & \multicolumn{2}{|l|}{$\mathrm{Al}$} & \multicolumn{2}{|l|}{$\mathrm{Si}$} \\
\hline & $\overline{R^{2}}$ & $R$ & $\overline{R^{2}}$ & $R$ & $\overline{R^{2}}$ & $R$ & $\overline{R^{2}}$ & $R$ \\
\hline \multicolumn{9}{|c|}{ Limestone $(n=19)$} \\
\hline Clay & $* 0.47$ & $* 0.69$ & $* 0.59$ & $* 0.77$ & $* 0.39$ & $* 0.63$ & $* 0.22$ & $* 0.47$ \\
\hline Sand & $* 0.44$ & $*_{-} 0.66$ & $* 0.51$ & $*-0.72$ & $* 0.40$ & $*-0.63$ & $* 0.29$ & $*-0.53$ \\
\hline Silt & $* 0.34$ & $* 0.59$ & $* 0.38$ & $* 0.61$ & $* 0.33$ & $* 0.58$ & $* 0.27$ & $* 0.52$ \\
\hline \multicolumn{9}{|c|}{ Siliceous stone $(n=61)$} \\
\hline Clay & $* 0.54$ & $* 0.74$ & $* 0.40$ & $* 0.63$ & $* 0.25$ & $* 0.50$ & $* 0.14$ & $*-0.37$ \\
\hline Sand & $* 0.59$ & $*-0.77$ & $* 0.44$ & $*-0.66$ & $* 0.34$ & $*-0.58$ & $* 0.11$ & $* 0.33$ \\
\hline Silt & $* 0.49$ & $* 0.70$ & $* 0.37$ & $* 0.61$ & $* 0.35$ & $* 0.59$ & $* 0.07$ & $*_{-0.26}$ \\
\hline \multicolumn{9}{|c|}{ Shale $(n=50)$} \\
\hline Clay & 0.06 & 0.25 & $* 0.02$ & $*-0.16$ & $* 0.09$ & $*-0.30$ & $* 0.13$ & $*-0.36$ \\
\hline Sand & $* 0.24$ & $*-0.49$ & 0.00 & 0.01 & 0.01 & -0.08 & 0.00 & 0.06 \\
\hline Silt & $* 0.30$ & $* 0.55$ & 0.03 & 0.16 & $* 0.23$ & $* 0.48$ & $* 0.10$ & $* 0.32$ \\
\hline \multicolumn{9}{|c|}{ Sandstone $(n=74)$} \\
\hline Clay & $* 0.21$ & $* 0.45$ & $* 0.09$ & $* 0.29$ & 0.02 & 0.14 & $* 0.11$ & $*-0.33$ \\
\hline Sand & $* 0.39$ & $*-0.62$ & $* 0.05$ & $*-0.39$ & $* 0.10$ & $*-0.32$ & 0.00 & 0.10 \\
\hline Silt & $* 0.27$ & $* 0.52$ & $* 0.08$ & $* 0.28$ & $* 0.12$ & $* 0.35$ & 0.03 & 0.17 \\
\hline \multicolumn{9}{|c|}{ Quartzite $(n=17)$} \\
\hline Clay & 0.01 & -0.10 & 0.04 & 0.21 & 0.12 & -0.34 & 0.01 & 0.09 \\
\hline Sand & 0.01 & -0.08 & 0.13 & -0.37 & 0.00 & 0.01 & 0.12 & -0.35 \\
\hline Silt & 0.09 & 0.31 & 0.25 & 0.50 & 0.17 & 0.41 & $* 0.36$ & $* 0.60$ \\
\hline
\end{tabular}

*p-value $<0.05$

the strongest relationships with \% sand and \% clay in soils derived from limestone and siliceous stones.

The relationship between $\%$ silt and the selected elements was the weakest among the PSD for most parent materials. The strongest relationship with the selected elements was for $\mathrm{Rb}$ in soils from siliceous stones $\left(R^{2}=0.49, r=0.70\right.$, $p<0.05)$, and the weakest relationship for $\%$ silt were $\mathrm{Fe}$ $(r=0.16, p>0.05)$ for shale and $\mathrm{Si}(r=0.17)$ for sandstone parent materials (Table 5). Furthermore, soils derived from quartzite had no significant relationship between the elements with \% clay, \% sand, and \% silt except between Si and $\%$ silt $\left(r=0.60, R^{2}=0.36\right)$.

These parent materials have different clay mineralogy (Ballantyne et al. 2006; Doff 2009), thus accounting for limestone and siliceous stone showing a stronger relationship between $\mathrm{Rb}$ and \% clay than sandstone, quartzite, and slate. Also, since $\mathrm{Rb}$ is adsorbed to clay after weathering and concentrates in potassium $(\mathrm{K})$ feldspar and mica, thus, the structure of different clay minerals is reflected by the concentration of $\mathrm{Rb}$ (Négrel et al. 2018). High concentration of $\mathrm{Rb}$ can be found in kaolinite and montmorillonite. Although there is limited information available on the clay mineralogy of the Irish soils, from Supplementary SF4, it can be inferred that the soils from granite, gneiss, quartzite, and slate may contain kaolinite and montmorillonite. Furthermore, higher $\mathrm{Rb}$ concentration reflects higher clay content (Zhu et al. 2011); however, some Irish soils did not follow this trend, which accounts for the weaker relationship observed in soils from granite, gneiss, quartzite, and slate. It is worth noting that the parent material in Ireland varies over short distances (Creamer et al. 2007); hence, there is a likelihood that the clay mineralogy may also vary.

Low concentration of $\mathrm{Rb}$ is associated with quartz and organic rich parent materials which results from increases in kaolinite, illite, and/or K-feldspar and muscovite (Négrel et al. 2018). The carboniferous limestone parent material distributed across Ireland is dominated by clays with high amounts of quartz and in some cases low levels of mica (Doff 2009). It could be that clay minerals in Irish soils with low concentrations of $\mathrm{Rb}$ have better correlation between $\mathrm{Rb}$ and $\%$ clay as compared to soils with higher concentrations of $\mathrm{Rb}$.

Clay minerals have different mechanical behaviour (Cherblanc et al. 2016), and in terms of weathering, Rb distribution and geochemistry is different in the individual clay types. Thus, soils derived from parent materials that do not weather easily such as slate, granite, and quartzite show a weak relationship between $\mathrm{Rb}$ and \% clay compared to soils from limestones which weather easily. In addition, soils from such parent material have high silica or hardened clay and retain more elements, explaining the high $\mathrm{Rb}$ concentration in these soils. Furthermore, each parent material has different weathering pattern and processes; hence, the weathered soils' have both physical and chemical characteristics unique 
to the parent material (Clemens et al. 2010; da Silva et al. 2016; Négrel et al. 2018). Thus, due to this unique geochemistry of the weathered soil, Mancini et al. (2020) were able to predict the parent material of Brazilian soils using portable XRF coupled with machine learning.

\subsubsection{Calibration and validation models}

$\mathrm{Rb}$ and Fe were selected to predict PSD based on the correlation and regression coefficients in Irish soils (Table 5). Also, soils derived from limestone, shale, and siliceous stone were chosen as suitable calibration (SIS dataset) and validation (HSP dataset) samples as these are representative of the parent material commonly found in Ireland. Prior to evaluating the linear regression model, the correlation between $\mathrm{Rb}$ and $\mathrm{Fe}$ was assessed to determine if there was the need to have separate models for each of the elements. It was observed that there was a statistically significant $(p<0.001)$ and strong relationship between the elements $\left(R^{2}=0.87\right.$, $r=0.93)$ of limestone and siliceous stone of the SIS data, as shown in Fig. 4.

Figure 5 illustrates the model performance for limestone and siliceous stone; for this study, samples for both parent

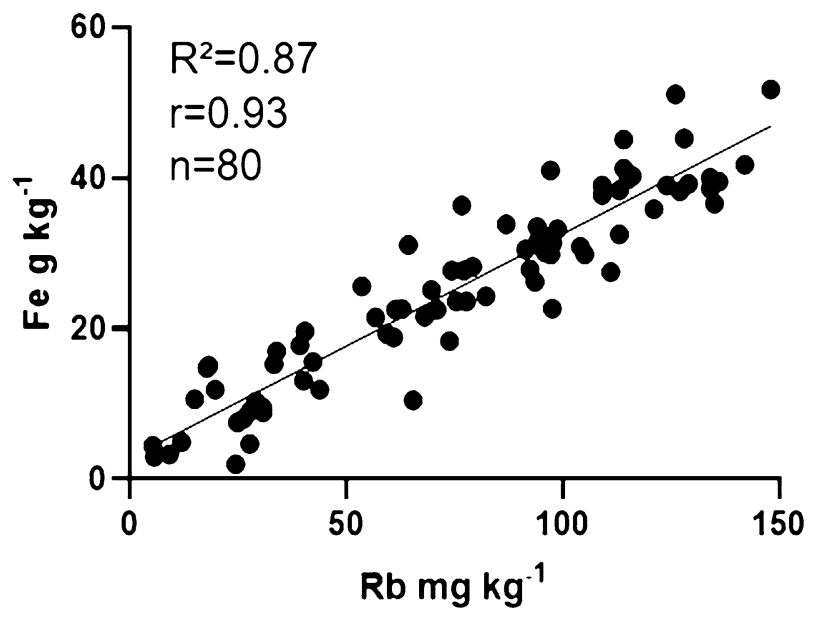

Fig. 4 Regression between $\mathrm{Rb}$ and Fe for soil samples selected for the calibration model for limestone and siliceous stones

materials were grouped. From the regression model shown in Fig. 5, there was a stronger relationship between $\mathrm{Rb}$ and $\%$ clay $\left(R^{2}=0.55\right)$ (Fig. 5a) compared to the Rb relationship with $\%$ sand $\left(R^{2}=0.49\right)$ (Fig. $\left.5 \mathrm{~b}\right)$ and $\%$ silt $\left(R^{2}=0.32\right)$ (Fig. 5c). However, for the independent validation, $\%$ sand

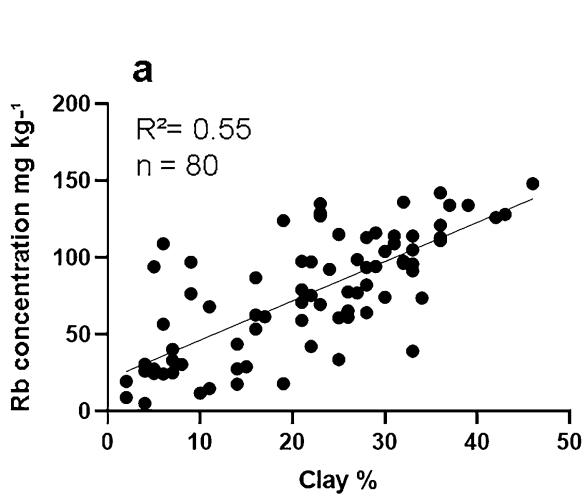

\section{Calibration}

b

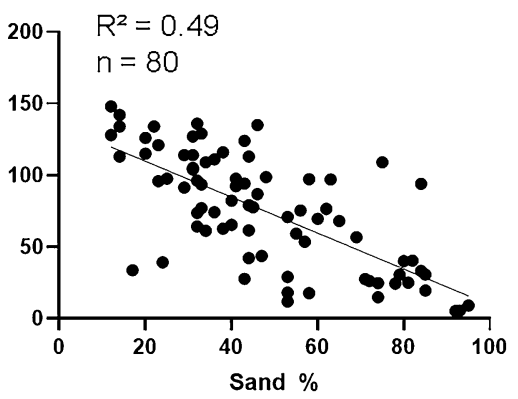

C

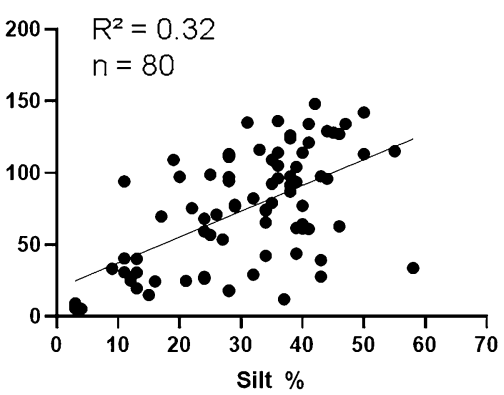

Validation
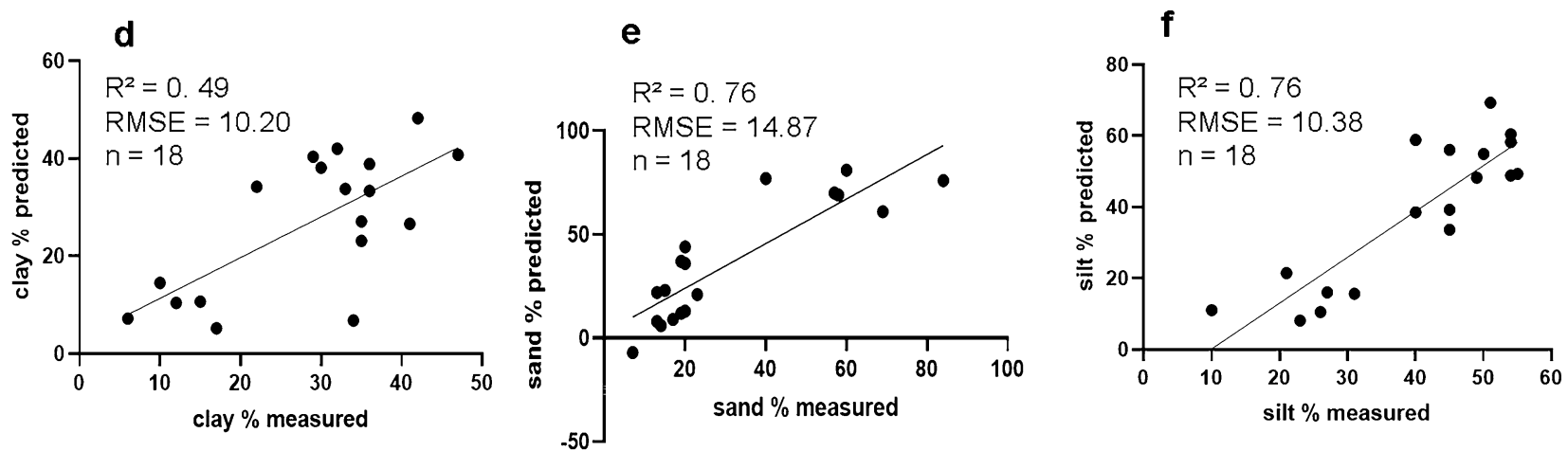

Fig. 5 Calibration and validation data using energy-dispersive $\mathrm{x}$-ray fluorescence spectrometer determined Rb concentration to predict particle size distribution in soils originating from limestone and siliceous stones 
(Fig. 5e) and \% silt (Fig. 5f) had a stronger relationship with $\mathrm{Rb}$ than \% clay (Fig. 5d). The samples' origin may account for the better performance of the HSP compared to the SIS datasets since the samples from the west of the country (Fig. 2) had a stronger relationship between $\mathrm{Rb}$ and \% clay than samples from the east with $\mathrm{Rb}$ 'hot spots'.

Evaluation of the regression model performance using RMSE showed that the prediction model for clay $(\mathrm{RMSE}=10.20 \%)$ and \% silt $(\mathrm{RMSE}=10.38 \%)$ performed better than \% sand (RMSE $=14.87 \%)$. Although RMSE $<10 \%$ is preferred and indicative of a good predictive technique, the RMSE in this study was slightly higher; however, the values for $\%$ clay and $\%$ silt were $<11 \%$. The poor performance of the regression model for $\%$ sand may have resulted from its limitations in predicting the samples with high silica content; since $\mathrm{Rb}$ is strongly sorbed to clay fractions in weathered soils, a soil with high silica content may be deficient in $\mathrm{Rb}$.

Also, the soil types used for the validation were not varied enough which may explain the poor performance of the models. Benedet et al. (2020) use a random forest algorithm to predict soil texture for Brazilian soils with portable XRF derived results and had RMSE's of the models $>30 \%$ for $\%$ sand, \% silt, and \% clay, although the $R^{2}$ was $>0.80$. In contrast, Silva et al. (2020), who also did a similar work with Brazilian soils, had RMSE values for random forest models of the $\%$ sand, $\%$ clay, and $\%$ silt $<10 \%$. Although the two studies were carried out using soils from the same region, the difference is that the latter study used soils of a wide range of soil types unlike the former study. Rubidiumdetermined EDXRF can be used for qualitative analysis and not a quantitative analysis of PSD in Irish soils from limestone and siliceous stone parent materials only.

\subsubsection{Evaluation of soil texture classification}

Analysis of PSD is an essential factor for determining soil texture. Information about soil texture helps to determine or infer various agronomic indicators such as soil organic carbon, bulk density, and the distribution of heavy metals (Keller and Håkansson 2010; Chandrasekaran and Ravisankar 2015; Rabot et al. 2018; Jensen et al. 2017; Shweizer et al. 2019). Figure 6 shows the comparison of the models developed from the EDXRF analysis to the gravimetric method; the USDA soil texture triangle was used for this study. Also, the use of a traffic light system was used to enhance the understanding of the visual displays, where green indicated a correct soil texture classification of the soil, yellow indicated minor misclassification of the sample close to its actual soil texture, and red indicated major misclassification of the model, placing the sample 2 to 3 classes away from its actual soil texture (Fig. 6). From Fig. 6, 39\% of the soils derived from limestone and siliceous stone were placed in the correct soil texture class, while another 39\% was placed close to the actual soil texture class and $22 \%$ placed in the wrong class.

\section{Pipette method}

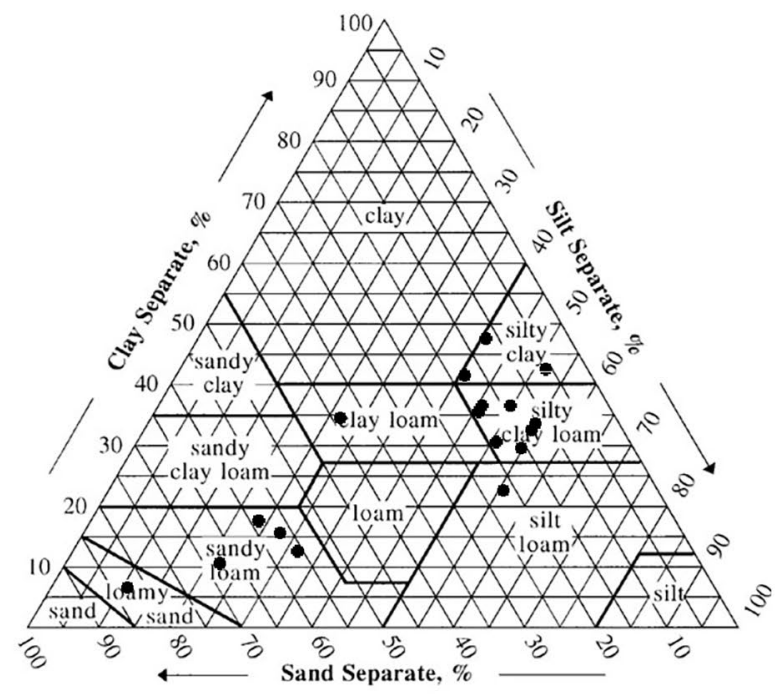

Fig. 6 Comparison of the gravimetric method to energy-dispersive $\mathrm{x}$-ray fluorescence spectrometer (EDXRF) for determining soil texture for soils originating from limestone and siliceous stones; green

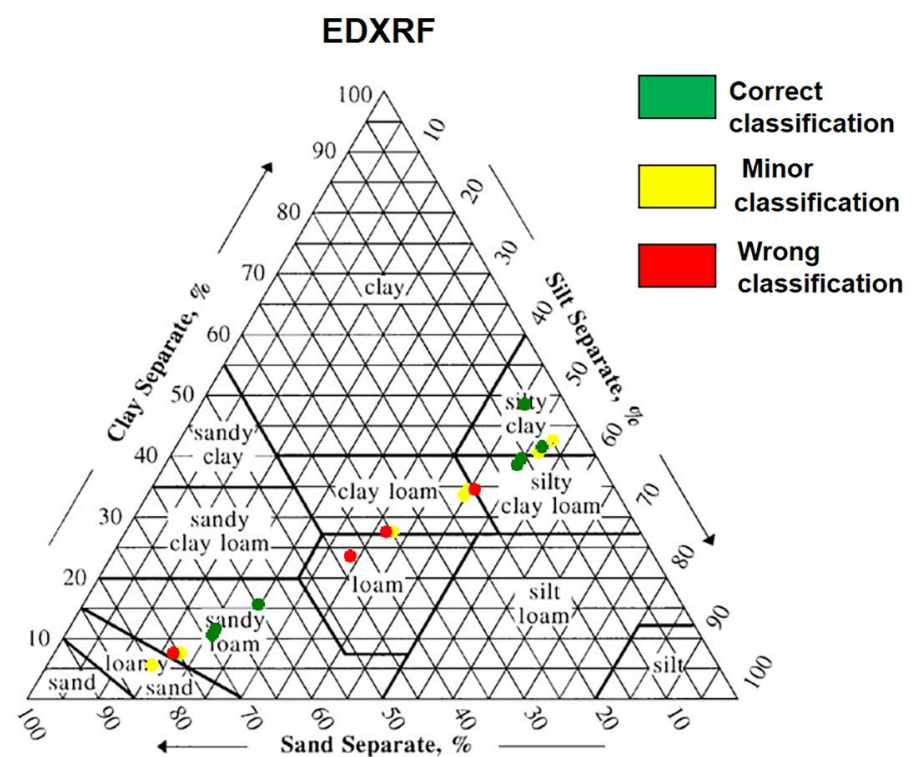

indicates a correct soil texture classification, yellow indicates a minor misclassification to a neighbouring texture class, and red indicates a major misclassification $(n=18)$ 
In Fig. 6, more than 50\% of the Irish soils evaluated had high silt content, and the soil types were distributed across 6 texture class, namely 8 silty clay loam, 3 silty clay, 1 silt loam, 1 clay loam, 4 sandy loam, and 1 sandy loam. Also, the model could predict almost all the sandy loam samples accurately. However, there were limitations with the prediction of silty types of soils, majority of the soil types that had major misclassification were silty clay loam. Thus, the model is more suitable for samples with high sand content than silt. Furthermore, Silva et al. (2020) observed that the prediction model for silt content was worse than both sand and clay content in Brazilian soils. This the authors' attribute to the moderate correlation between silt content and XRF measured elements as compared to sand and clay content which showed a stronger correlation with the elements. This finding agrees with the observation in this current study, whereby correlation between silt and $\mathrm{Rb}$ was weaker than correlation between $\mathrm{Rb}$ with both sand and clay content.

\section{Conclusion}

EDXRF can be used as a rapid screening method for \% clay in Irish soils, especially for examples originating from limestone and siliceous stone. $\mathrm{Al}$ and $\mathrm{Fe}$ correlated strongly with $\%$ sand and \% clay in soils derived from these parent materials; however, $\mathrm{Rb}$ was the most suitable marker to predict PSD in unknown soils. Also, this study has highlighted that the parent materials of the soils studied had a strong influence on the model's performance due to their geochemistry and clay mineralogy. Thus, the EDXRF has major difficulties in predicting $\%$ clay, $\%$ sand, and $\%$ silt in soils from parent materials that do not weather easily such as granite, gneiss, shale, and quartzite. Although the EDXRF was not as accurate as the gravimetric method, for predicting particle size compared to previous research, it has been shown previously that that the poor performance in soils derived from shale, quartzite, gneiss, and granite parent materials may result from the mineralogy of the soils as these parent materials are usually high in $\mathrm{Rb}$, and since $\mathrm{Rb}$ can be found in clay fractions, it is assumed that they are closely related. However, interestingly in Irish soils, the opposite was true, whereby samples from these parent materials had higher concentrations of $\mathrm{Rb}$ but lower \% clay due to their mineralogy. Future work may have to consider the clay mineralogy of soils derived from quartzite, shale, granite, and gneiss with X-ray diffraction and explore the use of data fusion with the EDXRF to model particle size distribution as an alternative to the gravimetric method for predicting PSD.

Supplementary Information The online version contains supplementary material available at https://doi.org/10.1007/s11368-021-03109-4.
Acknowledgements The authors would like to acknowledge Dr Patrick Tuohy for the access to HSP archives and databases, Dr Reámonn Fealy and Lilian O'Sullivan for the provision of additional data on SIS soil archives, Dr Konrad Metzger for the help with the creation of the map of Ireland, and Conor Nolan and Wendy Pierce for technical support.

Author contribution All authors contributed to the study conception and design. Writing-original draft, methodology, visualisation, formal analysis, investigation, and validation were performed by Maame Ekua Tawiah Croffie and resources and methodology by Anna Fenelon. Funding acquisition, conceptualisation, investigation, formal analysis, and supervision-writing reviewing and editing were performed by Paul Nicholas Williams, Owen Fenton, and Karen Daly and project administration by Karen Daly.

Funding This work was supported by the Teagasc Walsh Fellowship Programme (grant number RMIS 6502); and the Institute for Global Food Security, Queen's University Belfast (grant number A540IGFS).

Data availability The data is available upon reasonable requests to the corresponding author.

\section{Declarations}

Conflict of interest The authors declare no competing interests.

Open Access This article is licensed under a Creative Commons Attribution 4.0 International License, which permits use, sharing, adaptation, distribution and reproduction in any medium or format, as long as you give appropriate credit to the original author(s) and the source, provide a link to the Creative Commons licence, and indicate if changes were made. The images or other third party material in this article are included in the article's Creative Commons licence, unless indicated otherwise in a credit line to the material. If material is not included in the article's Creative Commons licence and your intended use is not permitted by statutory regulation or exceeds the permitted use, you will need to obtain permission directly from the copyright holder. To view a copy of this licence, visit http://creativecommons.org/licenses/by/4.0/.

\section{References}

Acosta JA, Martínez-Martínez S, Faz A, Arocena J (2011) Accumulations of major and trace elements in particle size fractions of soils on eight different parent materials. Geoderma 161(1-2):30-42. https://doi.org/10.1016/j.geoderma.2010.12.001

Ballantyne CK, McCarroll D, Stone JO (2006) Vertical dimensions and age of the Wicklow Mountains ice dome Eastern Ireland and implications for the extent of the last Irish Ice Sheet. Quater Sci Rev 25(17-18):2048-2058. https://doi.org/10.1016/j.quascirev. 2006.01.026

Ballantyne CK, McCaroll D and Stone JO (2011a) The Donegal ice dome, northwest Ireland: dimensions and chronology. Quat Sci 22(8) 773-783. https://doi.org/10.1002/jqs.1116

Ballantyne CK, McCaroll D and Stone JO (2011b) Periglacial trimlines and the extent of the Kerry-Cork Ice Cap, SW Ireland. Quat Sci Rev 30 3834-3845. https://doi.org/10.1016/jquascirev.2011.10.006

Benedet L, Faria WM, Silva SHG, Mancini M, Demattê JAM, Guilherme LRG, Curi N (2020) Soil texture prediction using portable X-ray fluorescence spectrometry and visible near-infrared diffuse reflectance spectroscopy. Geoderma 376. https://doi.org/ 10.1016/j.geoderma.2020.114553 
Beuselinck L, Govers G, Poesen J, Degraer G, Froyen L (1998) Grainsize analysis by laser diffractometry: comparison with the sievepipette method. CATENA 32(3-4):193-208. https://doi.org/10. 1016/S0341-8162(98)00051-4

Bisgård MK, Laursen J, Nielsen BS (1981) Energy-dispersive XRF spectrometry using secondary radiation in a Cartesian geometry. X-Ray Spectrom. https://doi.org/10.1002/xrs.1300100106

Chandrasekaran A and Ravisankar R (2015) Spatial distribution of physico-chemical properties and function of heavy metals in soils of Yelagiri hills, Tamilnadu by energy-dispersive X-ray spectroscopy (EDXRF) with statistical approach. Spectrochem Acta A Mol Biomol Spectrosc 150 586-601. https://doi.org/10.1016/jsaa. 2015.05.083

Cherblanc F, Berthonneau J, Bromblet P, Huon V (2016) Influence of water content on the mechanical behaviour of limestone: role of the clay minerals content. Rock Mech Rock Eng 49(6):20332042. https://doi.org/10.1007/s00603-015-0911-y

Clemens G, Fiedler S, Cong ND, Van Dung N, Schuler U, Stahr K (2010) Soil fertility affected by land use history, relief position and parent material under a tropical climate in NW-Vietnam Catena, 81:87-96. https://doi.org/10.1016/j.catena.2010.01.006

Creamer R, O'Sullivan L (2018) The soils of Ireland. Springer International Publishing AG, Cham- Switzerland

Creamer R, Simo I, Reidy B, Carvalho J, Fealy R, Hallet S, Jones R, Holden A, Holden N, Hannam J, Massey P, Mayr T, McDonald E, O’Rourke S, Sills P, Truckell I, Zawadzka J, Schulte R (2007) Irish soil information system-synthesis report no. 130

Croffie MET, Williams PN, Fenton O, Fenelon A, Metzger K, Daly K (2020) Optimising sample preparation and calibrations in EDXRF for quantitative soil analysis. Agronomy 10(9). https://doi.org/10. 3390/agronomy.10091309

da Silva FBV, do Nascimento CWA, Araúgo PRM, da Silva LHV, da Silv, RF (2016) Assessing heavy metal sources in sugarcane Brazilian soils: an approach using multivariate analysis. Envron. Monit. Assess. 144:457. https://doi.org/10.1007/ s10661-016-5409-x

Dexter AR (2004) Soil physical quality: Part I. Theory, effects of soil texture, density, and organic matter, and effects on root growth. Geoderma 120(3-4) 201-214. https://doi.org/10.1016/j.geoderma. 2003.09.004

Doff DH (2009) A clay mineralogy of Ireland. Ir J Earth Sci 271114.https://doi.org/10.3318/IJES.2009.27.11

Domonkos P, Coll J, Guijarro J, Curley M, Rustemeier E, Aguilar E, Walsh S, Sweeney J (2020) Precipitation trends in the island of Ireland using a dense, homogenized, observational dataset. Int $\mathbf{J}$ Climatol. https://doi.org/10.1002/joc.6592

Fay D, Kramers G, Zhang C, McGrath D, Grennan E (2007) Soil geochemical atlas of Ireland, Teagascand the Environmental Protection Agency, Ireland

Fenton O, Vero S, Ibrahim TG, Murphy PNC, Sheriff SC, Ó hUallacháin D (2015) Consequences of using different soil texture determination methodologies for soil physical quality and saturated zone time lag estimates. J Contam Hydrol 8216-24. https:// doi.org/10.1016/j.jconhyd.2015.07.004

Gee GW and Bauder JW (1986) Particle-size analysis in: Klute, A. (ED.) Method of soil analysis. Part 1 Physical and Mineralogical Methods

Gerlach RW and Nocerino JM (2003) Guidance for obtaining representative laboratory analytical subsamples from particulate laboratory samples, US Environmental Protection Agency report, EPA 600/R-03/027

Holland CH, Sanders IS (2009) The geology of Ireland, 2nd edn. Dunedin Academic Press, Edinburgh, Scotland

Ichikawa S, Nakamura T (2016) Approaches to solid sample preparation based on analytical depth for reliable X-ray fluorescence analysis. X-Ray Spectrom 45:302-307. https://doi.org/10.1002/ xrs. 2700

Jensen JL, Schjønning P, Watts CW, Christensen BT, Munkholm LJ (2017) Soil texture analysis revisited: removal of organic matter matters more than ever. PLoS ONE 12(5):1-10. https://doi.org/ 10.1371/journal.pone.0178039

Kalnicky DJ, Singhvi R (2001) Field portable XRF analysis of environmental samples. J Hazard Mater 83(1-2):93-122. https://doi. org/10.1016/S0304-3894(00)00330-7

Keller T, Håkansson I (2010) Estimation of reference bulk density from soil particle size distribution and soil organic matter content. Geoderma 154(3-4):398-406. https://doi.org/10.1016/j.geoderma. 2009.11.013

Lucadamo A, Leone A (2015) Principal component multinomial regression and spectrometry to predict soil texture. J Chemom 29(9):514-520. https://doi.org/10.1002/cem.2730

Mancini M, Silva SHG, Teixeira AFd-S, Guilherme LRG, Nilton C (2020) Soil parent material prediction for Brazil via proximal sensing. Geoderma Reg 22. https://doi.org/10.1016/jdeodrs.2020. e00310

Manousakas M, Diapouli E, Papaefthymiou H, Kantarelou V, Zarkadas C, Kalogridis A-C, Karydas A-G, Eleftheriadis K (2018) XRF characterization and source apportionment of PM10 samples collected in a coastal city. X-Ray Spectrom 47(3):190-200. https:// doi.org/10.1002/xrs.2817

Markowicz A (2011) An overview of quantification methods in energy-dispersive X-ray fluorescence analysis. Pramana- J of Phy 76:321-329

Melquiades FL, Bastos RO, Andreoni LS, Thomaz EL, Antoneli V (2019) Coupling soil transfer from hillslope to riparian zone through natural fingerprint in a catchment with tobacco crop. J Soils Sediments 19:1928-1936. https://doi.org/10.1007/s11368-018-2181-2

Melquiades FL, Appoloni CR (2004) Application of XRF and field portable XRF for environmental analysis. J Radioanal and Nucl Chem 262(2):533-541. https://doi.org/10.1023/B:JRNC. $0000046792.52385 . \mathrm{b} 2$

Meere P, MacCarthy I, Reavy J, Allen A, Higgs K (2013) Geology of Ireland: a field guide. The Collins Press, Cork

Négrel P, Ladenberger A, Reimann C, Birke M, Sadeghi M, the GEMAS Project Team (2018) Distribution of Rb, Ga and Cs in agricultural land soils at European continental scale (GEMAS): Implications for weathering conditions and provenance. Chem Geol 479:188-203. https://doi.org/10.1016/j.chemgeo.2018.01. 009

O'Rourke SM, Stockmann U, Holden NM. McBratney AB, Minasny B (2016) An assessment of model averaging to improve predictive power of portable vis-NIR and XRF for the determination of agronomic soil properties. Geoderma 279 31-44. https://doi.org/ 10.1016/j.geoderma.2016.05.005

Potts PJ, Williams-Thorpe O, Webb PC (1997) The Bulk Analysis of Silicate Rocks by Portable X-Ray Fluorescence: Effect of Sample Mineralogy in Relation to the Size of the Excited Volume. Geostand Geoanalytical Res 21(1):29-41. https://doi.org/10.1111/j. 1751-908X.1997.tb00529.x

Prout JM, Sheperd KD, McGrath SP, Kirk GJD, Haefele SM (2020) What is a good level of soil organic matter? An index based on organic carbon to clay ratio. Eur J Soil Sci 1-11. https://doi.org/ 10.1111/ejss. 13012

Rabot E, Wiesmeier M, Schlüter S, Vogel H-J (2018) Soil structure as an indicator of soil functions: a review. Geoderma 314122 137. https://doi.org/10.1016/j.geoderma.2017.11.009

Rouillon M, Taylor MP (2016) Can field portable X-ray fluorescence $(\mathrm{pXRF})$ produce high quality data for application in environmental contamination research? Environ Pollut 214:255-264. https://doi. org/10.1016/j.envpol.2016.03.055 
Sacristán D, Viscarra Rossel RA, Recatalá L (2016) Proximal sensing of $\mathrm{Cu}$ in soil and lettuce using portable X-ray fluorescence spectrometry. Geoderma 265:6-11. https://doi.org/10.1016/j. geoderma.2015.11.008

Schneider AR, Cancés B, Breton C, Ponthieu M, Morvan X, Conreux A, Marin B (2016) Comparison of field portable XRF and aqua regis/ICPAES soil analysis and the evaluation of soil moisture influence on FPXRF results. J. Soils Sediments 16:438-448. https://doi.org/10.1007/s11368-015-1252-X

Schweizer SA, Bucka FB, Graf-Rosenfeller M, Kögel-Knabner I (2019) Soil microaggregate size composition and organic matter distribution as affected by clay content. Geoderma 355. https://doi.org/10. 1016/j.geoderma.2019.113901

Shibata Y, Suyama J, Kitano M, Nakamura T (2009) X-ray fluorescence analysis of $\mathrm{Cr}, \mathrm{As}, \mathrm{Se}, \mathrm{Cd}, \mathrm{Hg}$, and $\mathrm{Pb}$ in soil using pressed powder pellet and loose powder methods. X-Ray Spectrom 38:410 416. https://doi.org/10.1002/xrs.1195

Silva SHG, Weindorf DC, Pinto LC, Faria WM, Acerbi Junior FW, Gomide LR, de Mello JM, de Pádua Junior AL, de Souza IA, dos Santos Teixeira AF, Guilherme LRG, Curi N (2020) Soil texture prediction in tropical soils: a portable X-ray fluorescence spectrometry approach. Geoderma 362. https://doi.org/10.1016/j. geoderma.2019.114136

Simo I, Schulte R, O'Sullivan L, Creamer R (2019) Digging deeper: understanding the contribution of subsoil carbon for climate mitigation, a case study of Ireland. Environ Sci Policy 98:61-69. https://doi.org/10.1016/j.envsci.2019.05.004

Swetha R, Chakraborty S (2021) Combination of soil texture with Nix color sensor can improve soil organic carbon prediction. Geoderma 382:114775. https://doi.org/10.1016/j.geoderma.2020. 114775

Takahashi G (2015) Sample preparation for X-ray fluorescence analysis III. Pressed and loose powder methods. Rigaku Journal 31:25-30
Taubner H, Roth B, Tippkötter R (2009) Determination of soil texture: comparison of the sedimentation method and the laser-diffraction analysis. J Plant Nutr Soil Sci 172(2):161-171. https://doi.org/10. 1002/jpln.200800085

Teagasc and Cranfield University Report (2014) Irish soil information system http://gis.teagasc.ie/soils/ (Accessed 19 February 2020)

Teagasc Heavy Soils Programme (2011) https://www.teagasc.ie/crops/ grassland/heavy-soils/ (Accesed 28 February 2020)

Tóth T, Kovács ZA, Rékási M (2019) XRF-measured rubidium concentration is the best predictor variable for estimating the soil clay content and salinity of semi-humid soils in two catenas. Geoderma 343:106-108. https://doi.org/10.1016/j.geoderma.2019.02.011

Wampler JM, Krogstad EJ, Elliot WC, Kahn B, Kaplan DI (2012) Long-term selective retention of natural $\mathrm{Cs}$ and $\mathrm{Rb}$ by highly weathered coastal plain soils. Environ. Sci. Tech. 46 3837-3843. https://doi.org/10.1021/es2035834

Wu C-M, Tsai H-T, Yang K-H, Wen JC (2012) How reliable is X-Ray fluorescence (XRF) measurement for different metals in soil contamination? Environ Forensics 13(2):110-121. https://doi.org/10. 1080/15275922.2012.676603

Zarkadas C, Karydas AG, Paradellis T (2001) Theoretical study of a secondary target XRF setup at different operational tube voltages. X-Ray Spectrom 30(2):99-109. https://doi.org/10.1002/xrs.479

Zaunbrecher LK (2015) Molecular models of Cesium and Rubidium adsorption on weathered micaceous minerals. J. Phys. Chem A. 119 5691-5700. https://doi.org/10.1021/jp512824k

Zhu Y, Weindorf DC and Zhang W (2011) Characterizing soils using a portable X-ray fluorescence spectrometer: 1. Soil texture. Geoderma 167-168167-177. https://doi.org/10.1016/j.geoderma. 2011.08.010

Publisher's Note Springer Nature remains neutral with regard to jurisdictional claims in published maps and institutional affiliations. 